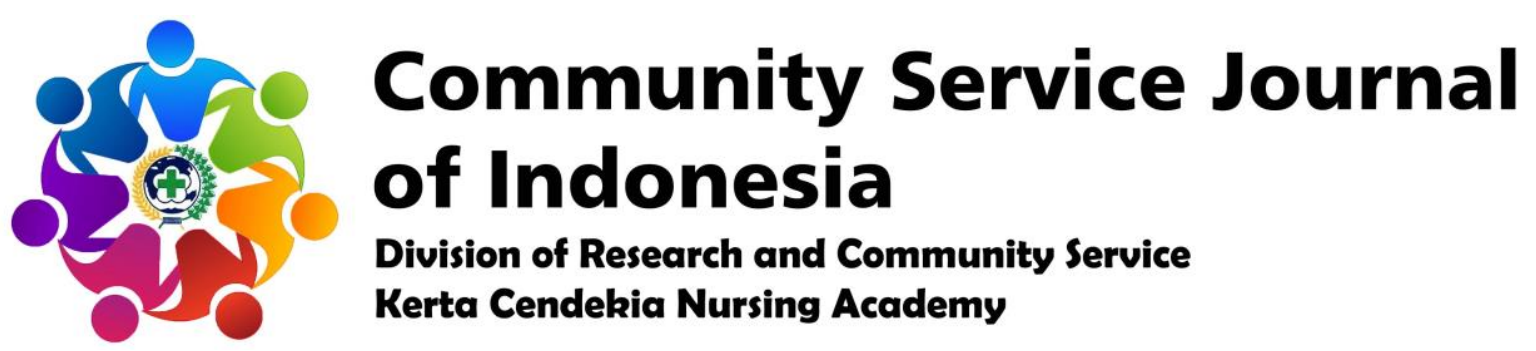

https://ejournal-kertacendekia.id/index.php/csji/index

\author{
Community Service Journal of Indonesia 2 (2) (2020): 21-23 \\ Doi: https://doi.org/10.36720/csji.v2i2.251
}

\title{
IMPROVEMENT OF KNOWLEDGE RELATED TO FIRST AID IN BURN CONDITIONS
}

\author{
Dini Prastyo Wijayanti ${ }^{*}$, Niken Ayu Sahella Putri ${ }^{2}$, Mei Nur Faiz Nabillah ${ }^{2}$, \\ Fachrudin Albar ${ }^{2}$, Annisa Fitriani ${ }^{2}$, Nurul Komariyah ${ }^{2}$, Asmaul Khusna ${ }^{2}$ \\ ${ }^{1}$ Lecturer of Kerta Cendekia Nursing Academy, Sidoarjo \\ ${ }^{2}$ Students of Kerta Cendekia Nursing Academy, Sidoarjo \\ * Correspondence \\ Dini Prastyo Wijayanti \\ Kerta Cendekia Nursing Academy, Sidoarjo \\ Lingkar Timur Road, Rangkah Kidul Village, Sidoarjo Sub-District, \\ Sidoarjo Regency, East Java Province, Indonesia - 61234 \\ Email: dinipw@gmail.com
}

\begin{abstract}
Health promotion activities regarding the first treatment of burns at Senior High School of Islam, Sidoarjo is a form of community service in the form of counseling aimed at increasing children's knowledge about how to treat first burns which are an injury incident that occurs due to exposure to high temperatures. (complex soft tissue injury). The implementation of these activities on December 18, 2019 took place at Senior High School of Islam, Sidoarjo. With the target is students of Senior High School of Islam, Sidoarjo. Prior to the implementation of these activities, there was a process of preparing activities for approximately 2 weeks before the activities were carried out, starting from determining the theme of the extension to applying for permits to the parties concerned. As a form of evaluation, this activity was attended by 47 students of class X and XI, participants joined the activity happily and looked very enthusiastic, health promotion activities could run on time and smoothly.
\end{abstract}

Keywords: First aid, burn condition, health promotion.

(c) 2020 The Authors. Community Service Journal of Indonesia Published by Community Service and Research of Kerta Cendekia Nursing Academy - Kerta Cendekia Nursing Academy

This is an Open Access Article distributed under the terms of the Creative Commons Attribution 4.0 International License which permits unrestricted non-commercial use, distribution, and reproduction in any medium, provided the original work is properly cited.

E-ISSN

2684-7884

\section{INTRODUCTION}

Burns are trauma caused by heat, electric current, chemicals and lightning on the skin, mucosa and deeper tissues (Anonymous, 2001). Extensive burns affect the metabolism and function of every cell 
in the body, all systems can be disrupted, especially the cardiovascular system. Burns can be divided into: first degree, second superficial, second deep, and third degree. First degree burns only affect the epidermis with erythema and pain. Superficial second-degree burns extend to the epidermis and part of the dermis and are blistered and very painful. Deep seconddegree burns extend throughout the dermis. Third degree burns extend to the epidermis, dermis, and subcutis tissue, often the capillaries and veins are scorched and blood to these tissues is reduced (Corwin, 2009). Handling in healing burns includes preventing infection and allowing the remnants of epithelial cells to proliferate and cover the wound surface (Syamsuhidayat and Jong, 1997).

\section{OBJECTIVES}

\section{General Purpose}

After providing counseling by students for 45 minutes, it is hoped that the students of class X-XI on Senior High School of Islam, Sidoarjo can understand the importance of first aid for burns.

\section{Special Purpose}

After 45 minutes of health education by students, it is hoped that the students of Senior High School of Islam, Sidoarjo can:

1. Understand about burns condition.

2. Know the etiology of burns condition.

3. Know the classification of burns condition.

4. Know how to treat burns.

\section{PLAN OF ACTION}

Strategy Plan

The strategy plan implemented, including:

1. Coordinate with the principal of Senior High School of Islam, Sidoarjo to apply for permission to implement health education as a nursing program and to help provide useful knowledge for the students of Senior High School of Islam, Sidoarjo.

2. Determine time contracts with the students of the Senior High School of Islam, Sidoarjo.

3. Provide health education about the first treatment at the time of burns.

\section{Implementation}

Actions taken in the implementation of these activities, including:

1. Contacted the principal of the Senior High School of Islam, Sidoarjo to request permission to carry out the activity and gathered the students of the Senior High School Islam, Sidoarjo.

2. Prepared a place and media for health education about the burns condition.

3. Delivery of health education materials about the burns condition to the students of Senior High School Islam, Sidoarjo.

\section{Setting}

This activity was carried out at the Senior High School Islam, Sidoarjo on December 18, 2019.

Target

Target in this activity is all of the students of class $\mathrm{X}$ and XI of the Senior High School Islam, Sidoarjo around 47 students.

\section{RESULTS AND DISCUSSION}

This activity took place on December 18, 2019 which lasted for one hour starting at 08.00 WIB until 09.00 WIB. Activities carried out according to plan. This activity was attended by around 47 students of class X - XI of Senior High School of Islam, 
Sidoarjo. The media used in the implementation of this health education include laptops, powerpoints, videos, leaflets, LCDs, and posters. The implementation of health education activities is carried out using language and health education techniques that are easy to understand and attractive to health education participants. This health counseling activity can be said to be successful because during its implementation the participants seemed enthusiastic and no one left the extension site. In addition, there were several participants who asked questions related to the explanation given by the presenter. In the final evaluation of the activity, data was obtained that $90 \%$ of health education participants were able to explain the definition of burns, the etiology of burns, and the classification of burns. In addition, data also showed that $80 \%$ of the participants in this health education activity were able to re-demonstrate how to handle burns.

\section{CONCLUSION}

With the holding of this health education activity, it is hoped that each participant of this counseling activity can provide first aid to people who have burns. This is because most of the participants $(80 \%)$ have been able to re-demonstrate the treatment of burns.

\section{REFERENCES}

Retrieved
http://vickyaldion.blogspot.com/20
14/10/makalah-luka-bakar_18.html
on November 18, 2019.
from
from

https://id.wikipedia.org/wiki/Luka bakar on November 19, 2019.

American College of Surgeons Committee on Trauma. (1997). Advanced Trauma Life Support Program for Doctors: ATLS. American College of Surgeons Committee on Trauma.

Corwin, E. J. (2009). Buku saku patofisiologi. Jakarta: EGC.

Darwono, A. B., \& Sutoko, F. Protokol Pengelolaan Luka Bakar. Semarang: Bagian Bedah FK Universitas Diponegoro.

Honniasih, M. (2011). EFEK PENYEMBUHAN LUKA Bakar Gel Lendir Bekicot (Achatina Fulica) Dengan Hidroksipropil Methylcellulose (Hpmc) Sebagai Gelling Agent Pada Kulit Punggung Kelinci Jantan (Doctoral dissertation, Univerversitas Muhammadiyah Surakarta).

Na'imah, S. (2019). Luka Bakar. Retrieved from https://hellosehat.com/hidupsehat/pertolongan-pertama/lukabakar/ on November 18, 2019.

Riasa, I. N. P. (2003). Memahami Luka Bakar. Retrieved from http://library.um.ac.id/majalah/prin tmajalah4.php/16766.html.

Syamsuhidayat, R., \& Jong, W. D. (1997). Buku Ajar Ilmu Bedah: Luka Bakar. Jakarta: Erlangga. 